\title{
Effect of starters on gross and microbiological composition and organoleptic characteristics of Graviera Kritis cheese
}

\author{
Ioannis G. Kandarakis*, Ekaterini E. Moschopoulou, \\ Golfo A. Moatsou, Emanouil M. Anifantakis
}

Laboratory of Dairy Research, Department of Food Science and Technology, Agricultural University of Athens, Iera Odos 75, 11855 Athens, Greece

(Received 1 December 1997; accepted 23 April 1998)

\begin{abstract}
The use of different starter cultures in the manufacture of Graviera Kritis cheese for improving its overall quality was investigated. Mixtures of Streptococcus thermophilus, Lactobacillus helveticus (1:1) and Propionibacterium freundreichii subsp. shermanii (cheese A); Lactococcus lactis subsp. lactis, L. lactis subsp. cremoris, S. thermophilus, L. helveticus $(1: 1: 10: 2)$ and P. freundreichii subsp. shermanii (cheese B); and L. lactis subsp. lactis, L. lactis subsp. cremoris, $S$. thermophilus, $L$. helveticus $(2.5: 2.5: 1: 1)$ and $P$. freundreichii subsp. shermanii (cheese C) were used and compared with cheese D made without starter cultures. The gross composition of the matured cheeses A, B and C was not significantly $(P<0.05)$ affected, although their $\mathrm{pH}$ values and their ash and salt contents were significantly $(P<0.05)$ lower than that of cheese $\mathrm{D}$ at the beginning of ripening. Regarding the cheese microflora, coliforms were not found in cheeses A, B and C after $60 \mathrm{~d}$ of ripening, while they were still detectable in matured $(90 \mathrm{~d})$ cheese D. Enterococci counts in matured cheeses A, B and C were significantly $(P<0.05)$ lower than in cheese D, while the other groups of microorganisms were not significantly affected. Finally, no significant difference $(P<0.05)$ was detected in the flavour, body and texture of the cheeses made with the starter cultres. (c) Inra/Elsevier, Paris.
\end{abstract}

Graviera Kritis cheese / starter culture / gross composition / microbiological composition

Résumé - Influence des levains sur la composition grossière et microbiologique et les caractéristiques sensorielles du fromage Graviera Kritis. Le Graviera Kritis est un fromage grec d' « appellation d'origine controlée » (AOC) qui traditionnellement subit une fermentation propionique limitée sans ajout de levains au lait de fabrication. L'utilisation de différents levains en production de fromage Graviera Kritis a été examinée afin d'améliorer sa qualité globale. Des combinaisons de Streptococcus thermophilus, Lactobacillus helveticus (1:1) et Propionibacterium freundreichii subsp. shermanii (fromage A) ; Lactococcus lactis subsp. lactis, L. lactis subsp. cremoris,

\footnotetext{
* Correspondence and reprints. E-mail: ykan@auadec.aua.gr
} 
S. thermophilus, L. helveticus (1:1:10:2) et $P$. freundreichii subsp. shermanii (fromage B) ; et L. lactis subsp. lactis, $L$. lactis subsp. cremoris, $S$. thermophilus, $L$. helveticus $(2.5: 2.5: 1: 1)$ et $P$. freundreichii subsp. shermanii (fromage C) ont été utilisées et comparées au fromage D fabriqué sans levains. La composition grossière des fromages affinés n'a pas été significativement influencée par l'emploi des levains. En revanche, en début d'affinage le $\mathrm{pH}$ et la concentration en cendres et en sel des fromages A, B et C étaient significativement $(p<0,05)$ inférieurs à ceux du fromage D. En ce qui concerne les caractéristiques microbiologiques, aucun coliforme n'a été détecté dans les fromages A, B et C pendant les 60 jours d'affinage alors que ces bactéries étaient encore détectables dans le fromage $\mathrm{D}$ affiné ( 90 jours). De même, le nombre des entérocoques était significativement $(p<0,05)$ inférieur dans les fromages A, B et C par rapport au fromage D. En revanche, les autres groupes de microorganismes n'étaient pas significativement influencés. Aucune différence significative $(p<0,05)$ n'a été constatée quant aux caractéristiques organoleptiques des fromages. () Inra/Elsevier, Paris.

\section{fromage Graviera Kritis / levain / composition / microbiologie}

\section{INTRODUCTION}

Graviera Kritis is a Controlled Denomination of Origin cheese [8] which is produced in Crete island of Greece. It is a Gruyère-type cheese which, however, undergoes a limited propionic acid fermentation and so differs from the Swiss-type cheeses in many ways.

The typical Swiss-type cheeses such as Emmentaler, Gruyère and Appenzeller are made from cows' milk using starter cultures which contain thermophilic lactic acid bacteria such as Streptococcus thermophilus, Lactobacillus helveticus, Lactobacillus delbrueckii subsp. lactis and/or Lactobacillus bulgaricus. Propioniobacteria (mainly Propionibacterium freudenreichii subsp, shermanii) are also used. They give to these cheeses their characteristic sweet flavour and eyes in the cheese body [27].

The Greek Gruyère-type cheeses are little studied and so the available literature for their characteristics is very scarce $[28,1$, 29]. A typical composition of Greek Gruyère-type cheese made from ewes' milk, scalded at $48-50^{\circ} \mathrm{C}$ and ripened for 90 days is usually the following: $\mathrm{pH} 5.7$, dry matter $64.9 \%$, fat in dry matter $54.6 \%$ and salt in moisture $3.6 \%$ [18]. The gross composition and the native microflora of Graviera Kritis cheese have never been studied before.
Graviera Kritis is traditionally made from ewes' or a mixture of ewes' milk with low percentage of goats' milk heated up to $68-70{ }^{\circ} \mathrm{C}$. None starter cultures are added and the cheese curd is heated to $50-52^{\circ} \mathrm{C}$. The cheese wheel is salted in brine 16-20\% for 4 to $5 \mathrm{~d}$, ripens at $15-16{ }^{\circ} \mathrm{C}$ for $90 \mathrm{~d}$ and has a rind with surface smear. The matured cheese wheel usually has a diameter of $40 \mathrm{~cm}$ and a weight of $14-16 \mathrm{~kg}$. Finally, because of the type of milk and the technology used, Graviera Kritis cheese has a distinctive but not sweet flavour, non-elastic texture and usually lacks openness.

Unfortunately, the overall quality of Graviera Kritis cheese is not always the desired one mainly because of the poor microbiological quality of the raw milk used. Raw milk is usually heavily contaminated by microorganisms, as it is collected without milking machines in faraway farms of a mountainous region and under high temperatures, especially during spring. Thus, the milk combined with the insufficient pasteurization and the absence of starter cultures yield cheeses without standardized overall quality.

The aim of this work was to study the gross composition and the microflora of Graviera Kritis cheese and to improve its characteristics by using starter cultures without, however, changing its typical flavour. 


\section{MATERIALS AND METHODS}

\subsection{Cheesemaking}

In the spring time, three trials of cheesemakings were carried out in a cheese factory at Rethimnos of Crete, according to the experimental protocol shown in figure 1 .

On average, the raw milk contained in colonyforming units (cfu) $/ \mathrm{mL}$ : aerobic mesophilic microflora $2.5 \times 10^{8}$, thermophilic streptococci $3.7 \times 10^{8}$, mesophilic lactobacilli $1.0 \times 10^{8}$, enterococci $0.3 \times 10^{8}$, coliforms $1.6 \times 10^{7}$ and propionibacteria $2.0 \times 10^{3}$. After heating, the cheese milk used had the following average counts of microorganisms: aerobic mesophilic microflora $1.4 \times 10^{5}$, thermophilic streptococci $0.9 \times 10^{5}$, mesophilic lactobacilli $0.3 \times 10^{5}$, enterococci $0.1 \times 10^{4}$, coliforms $1.4 \times 10^{3}$ and propionibacteria $0.5 \times 10^{3} \mathrm{cfu} / \mathrm{mL}$.

Mesophilic and thermophilic lactic acid starters as well as propionic acid starter cultures were used. The mesophilic lactococci $L$. lactis, which produce only L-lactate, were selected to promote the propionibacteria growth, because propionibacteria use L-lactate in preference to $\mathrm{D}$-lactate [10]. The cultures added to cheeses A, B and C were freeze-dried cultures for direct vat inoculation and were obtained from Wiesby (Wiesby GmbH \& Co, Niebull, Germany), EZAL- Rhone Poulenc (Dange Saint-Romain, France) and Hansen (Horsholm, Denmark), respectively.

The rennet used was mixture (1:1) of calf rennet 'Hipirotopoula' (A. Tsakanikas, Greece) and Fermentation Produced Chymosin 'MAXIREN' (Gist-Brocades, France). The $\mathrm{pH}$ of milk at which rennet was added was 6.35 .

\subsection{Microbiological, chemical and organoleptic analyses}

All cheeses were analyzed at 1 (after pressing), 13, 30, 60, 90 and $180 \mathrm{~d}$ of ripening.

Microflora was measured by the means of the pour plate method using the following differential media:

- Mesophilic aerobic microflora: plate count agar (Biokar, France), at $30^{\circ} \mathrm{C}$ for $3 \mathrm{~d}$;

- Thermophilic streptococci: M-17 agar (Biokar) at $37^{\circ} \mathrm{C}$ for $2 \mathrm{~d}$;

- Mesophilic lactobacilli: MRS agar (Oxoid, $\mathrm{UK}$ ), with $\mathrm{pH}$ 5.4-5.6, incubated anaerobically at $37{ }^{\circ} \mathrm{C}$ for $2 \mathrm{~d}$;
- Propionibacteria: sodium lactate agar with cloxacillin (SLAC) as it is described by Drinan and Cogan [12];

- Coliforms: according to the IDF method [17];

- Enterococci: Kanamycin Aesculin Azide agar (Oxoid, UK) according to Oxoid manual instructions;

- Anaerobic spore-forming microorganisms: with the most probable number method in RCM broth (Biokar, France) incubated anaerobically at $37^{\circ} \mathrm{C}$ for $14 \mathrm{~d}$.

For the $\mathrm{pH}$ determination, $10 \mathrm{~g}$ of cheese was first homogenized with $10 \mathrm{~mL}$ distilled water. The dry matter content was determined by heating at $102^{\circ} \mathrm{C}$ to constant weight, the ash content by charring at $550^{\circ} \mathrm{C}$ to constant weight, the fat content by the Gerber method and the salt content as suggested by Anifantakis [2].

Finally, all cheeses were assessed organoleptically by a ten member panel for the flavour (scale $0-45$ ) and body and texture characteristics (scale $0-35$ ) at 90 and $180 \mathrm{~d}$ of ripening.

\subsection{Statistical analyses}

The microbiological data, expressed as $\log _{10} \mathrm{cfu}$, organoleptical and chemical data were subjected to one way analysis of variance at a 95\% level of significance and to multiple range test using the LSD-test (LSD: least significant difference). Furthermore, regression analysis for the data from chemical analyses was applied at the same level of significance. For all data manipulations the statistical software STATGRAPHICS v.6. was used.

\section{RESULTS AND DISCUSSION}

\subsection{Gross composition}

It has been shown that the level of $S$. thermophilus and the strain of lactobacillus used in Swiss-type cheeses affect the $\mathrm{pH}$ of curd before and after draining, respectively [24] and that high quality Swiss cheeses usually have $\mathrm{pH}$ value 5.64-5.7 [21]. In this experiment, the $\mathrm{pH}$ value of cheeses $\mathrm{A}, \mathrm{B}$ and $\mathrm{C}$ made with starter cultures was significantly $(P<0.05)$ lower than the $\mathrm{pH}$ of cheese D made without starters at the first day of 


\section{MILK (Ewes': Goats'/9:1) \\ $\downarrow$ \\ HEATING at $70^{\circ} \mathrm{C}$ for $15 \mathrm{sec}$}

\section{COOLING to $35^{\circ} \underline{\mathrm{C}}$}

\begin{tabular}{|c|c|c|c|}
\hline Cheese A & Cheese B & Cheese C & Cheese D \\
\hline$\downarrow$ & $\downarrow$ & $\downarrow$ & $\downarrow$ \\
\hline \multicolumn{4}{|c|}{ Starter cultures $/ 100 \mathrm{~kg}$ milk } \\
\hline$\downarrow$ & $\downarrow$ & $\downarrow$ & \\
\hline $3.2 \mathrm{~g}$ of & $1.2 \mathrm{~g}$ of & $1.85 \mathrm{~g}$ of & $\downarrow$ \\
\hline $\begin{array}{l}\text { S. thermophilus and } \\
\text { L. helveticus }(1: 1) \text { and }\end{array}$ & $\begin{array}{l}\text { L. lactis subsp. lactis, } \\
\text { L. lactis subsp. cremoris }\end{array}$ & $\begin{array}{l}\text { L. lactis subsp. lactis } \\
\text { L. lactis subsp. cremoris, }\end{array}$ & \\
\hline $0.4 \mathrm{~g}$ of $P$. freundreichii & S. thermophilus, & S. thermophilus, & $\downarrow$ \\
\hline subsp. shermanii, & $\begin{array}{l}\text { L. helveticus }(1: 1: 10: 2) \text { and } \\
0.4 \mathrm{~g} \text { of } P \text {. freundreichii } \\
\text { subsp. shermanii } \\
\quad \downarrow\end{array}$ & $\begin{array}{l}\text { L. helveticus }(2.5: 2.5: 1: 1) \text { and } \\
0.4 \mathrm{~g} \text { of } P . \text { freundreichii } \\
\text { subsp. shermanii } \\
\downarrow\end{array}$ & nd \\
\hline
\end{tabular}

RENNETING: $2.5 \mathrm{~g}$ rennet $/ 100 \mathrm{~kg}$ milk

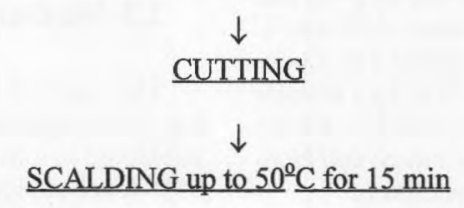

$\downarrow$
LEAVING for $50 \mathrm{~min}$

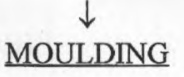

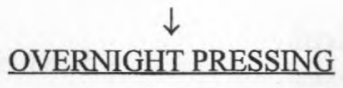

REMAINING without moulds at $21-24^{\circ} \mathrm{C}$ for $1 \mathrm{~d}$

$\downarrow$

SALTING in brine solution $16 \%$ for $3 \mathrm{~d}$

$\downarrow$

RIPENING at $15^{\circ} \mathrm{C}$ for 2 months and then at $4^{\circ} \underline{\mathrm{C}}$

Figure 1. Flow diagram of the manufacture of Graviera Kritis cheese with different mixtures of starter cultures.

Figure 1. Diagramme de fabrication du fromage Graviera Kritis avec différents levains. 
Table I. $\mathrm{pH}$, dry matter and ash contents ${ }^{1}$ during ripening of Graviera Kritis cheese made with different starter cultures.

Tableau I. Valeurs ${ }^{1}$ du pH, de l'extrait sec et des cendres pendant l'affinage du fromage Graviera Kritis fabriqué avec différents levains.

\begin{tabular}{|c|c|c|c|c|c|c|c|c|c|c|c|c|}
\hline \multirow[t]{2}{*}{ Time (d) } & \multicolumn{4}{|c|}{$\mathrm{pH}$} & \multicolumn{4}{|c|}{ Dry matter \% } & \multicolumn{4}{|c|}{ Ash \% } \\
\hline & $\mathrm{A}^{2}$ & $\mathrm{~B}^{3}$ & $\mathrm{C}^{4}$ & $\mathrm{D}^{5}$ & A & B & $\mathrm{C}$ & $\mathrm{D}$ & A & B & $\mathrm{C}$ & $\mathrm{D}$ \\
\hline 1 & $5.07^{\mathrm{a}^{*}}$ & $5.08^{\mathrm{a}}$ & $5.07^{\mathrm{a}}$ & $5.32^{\mathrm{b}}$ & $59.92^{\mathrm{a}, \mathrm{b}}$ & $60.08^{\mathrm{a}, \mathrm{b}}$ & $60.70^{\mathrm{b}}$ & $57.69^{\mathrm{a}}$ & $2.67^{\mathrm{a}}$ & $2.73^{\mathrm{a}, \mathrm{b}}$ & $2.64^{\mathrm{a}}$ & $2.83^{\mathrm{b}}$ \\
\hline 13 & 5.21 & 5.21 & 5.21 & 5.22 & $63.21^{\mathrm{a}, \mathrm{b}}$ & $62.99^{\mathrm{a}, \mathrm{b}}$ & $63.59^{\mathrm{b}}$ & $61.65^{\mathrm{a}}$ & 3.63 & 3.64 & 3.54 & 3.83 \\
\hline 30 & 5.35 & 5.27 & 5.29 & 5.33 & 63.78 & 64.47 & 63.41 & 62.97 & 3.90 & 4.15 & 3.91 & 4.21 \\
\hline 60 & 5.39 & 5.33 & 5.37 & 5.32 & $65.60^{\mathrm{b}}$ & $63.51^{a, b}$ & $63.96^{\mathrm{a}, \mathrm{b}}$ & $62.55^{\mathrm{a}}$ & 4.08 & 3.83 & 3.86 & 4.00 \\
\hline 90 & 5.53 & 5.44 & 5.49 & 5.52 & 65.42 & 64.31 & 65.31 & 64.30 & 4.33 & 4.16 & 4.14 & 4.19 \\
\hline 180 & 5.50 & 5.49 & 5.51 & 5.51 & $66.20^{\mathrm{b}}$ & $65.61^{a, b}$ & $65.28^{a, b}$ & $64.77^{\mathrm{a}}$ & 4.28 & 4.24 & 4.36 & 4.53 \\
\hline
\end{tabular}

${ }^{1}$ Mean values from three trials. ${ }^{2} S$. thermophilus $+L$. helveticus $(1: 1)+$ Propionibacterium freudenreichii subsp. shermanii. ${ }^{3} L$. lactis subsp. lactis $+L$. lactis subsp. cremoris $+S$. thermophilus $+L$. helveticus $(1: 1: 10: 2)+$ Propionibacterium freudenreichii subsp. shermanii. ${ }^{4} L$. lactis subsp. lactis $+L$. lactis subsp. cremoris $+S$. thermophilus $+L$. helveticus $(2.5: 2.5: 1: 1)+$ Propionibacterium freudenreichii subsp. shermanii. ${ }^{5}$ Without starters. ${ }^{*}$ Means in the same row, followed by different superscript differ significantly $(P<0.05)$.

${ }^{1}$ Valeurs moyennes de trois essais. ${ }^{2} S$. thermophilus $+L$. helveticus $(1: 1)+$ Propionibacterium freudenreichii subsp. shermanii. ${ }^{3} L$. lactis subsp. lactis $+L$. lactis subsp. cremoris + S. thermophilus $+L$. helveticus $(1: 1: 10: 2)+$ Propionibacterium freudenreichii subsp. shermanii. ${ }^{4} L$. lactis subsp. lactis $+L$. lactis subsp. cremoris $+S$. thermophilus $+L$. helveticus $(2.5: 2.5: 1: 1)+$ Propionibacterium freudenreichii subsp. shermanii. ${ }^{5}$ Sans levains. $*$ Les valeurs moyennes d'une même ligne suivies de lettres différentes differrent significativement. 
ripening (table I) and this difference is attributed to the activity of the thermophilic lactic acid starters added. At the end of ripening, however, $\mathrm{pH}$ values of all cheeses were similar to each other, but they were lower than $\mathrm{pH}$ of Greek Gruyère made from cows' milk [29] and higher than $\mathrm{pH}$ of Gruyèretype cheese made by Anifantakis et al. [1]. Furthermore, the $\mathrm{pH}$ changes in cheeses $\mathrm{A}$, $\mathrm{B}$ and $\mathrm{C}$ were more significantly correlated with the age of the cheese (multiplicative model $r=0.94, r=0.95$, and $r=0.95$, respectively) than in cheese $\mathrm{D}$ (linear model $r=0.74$ ). Thus, $\mathrm{pH}$ of cheeses $\mathrm{A}, \mathrm{B}$ and $\mathrm{C}$ increased rapidly during the first $30 \mathrm{~d}$ of ripening, while $\mathrm{pH}$ of traditional cheese $\mathrm{D}$ increased gradually, because lactose was fermented by the native microflora. According to Martley and Crow [25], the nonstarter lactic acid bacteria (NSLAB) in a cheese ferment the lactose slowly, increase in numbers and then maintain constant throughout ripening.

The dry matter content of cheese $C$ was significantly $(P<0.05)$ higher than the dry matter content of cheese $D$ at 1 and $13 \mathrm{~d}$ of ripening (table $I$ ). The difference at $1 \mathrm{~d}$ is the most important and can be attributed to the higher $\mathrm{pH}$ value of cheese $\mathrm{D}$ at that time. The $\mathrm{pH}$ value affects the ability of casein micelles to absorb water and as $\mathrm{pH}$ increases up to the maximum level 5.5 the water absorption also increases $[9,24]$. Compared with other Greek Gruyère-type cheese from ewes' milk [28], all matured cheeses of this experiment had slightly lower dry matter content due probably to goats' milk used. Finally, the changes in the dry matter content of all cheeses were significantly correlated with the age of the cheeses (multiplicative model $r=0.94$ in cheese A, $r=0.91$ in cheese $\mathrm{B}, r=0.92$ in cheese $\mathrm{C}$ and $r=0.94$ in cheese D).

Significant $(P<0.05)$ differences in the ash content of all cheeses were observed only at $1 \mathrm{~d}$ of ripening (table I). Cheeses A, $B$ and $C$ had lower ash content than cheese D. This was expected because the rapid $\mathrm{pH}$ decrease in a cheese curd during the stage of draining causes intense removal of colloidal calcium phosphate from the casein micelles and consequently high mineral loss from the curd $[6,24]$. The ash contents of cheeses $\mathrm{A}, \mathrm{B}$ and $\mathrm{C}$ were significantly correlated ( $r=0.89$ in cheese A, $r=0.80$ in cheese $\mathrm{B}, r=0.85$ in cheese $\mathrm{C}$ and $r=0.38$ in cheese $\mathrm{D}$ ) with the respective $\mathrm{pH}$ values, confirming thus the effect of the curd acidification on the mineral removal. The results for the ash content are similar to those obtained by Veinoglou et al. [28], concerning Greek Gruyère-type cheese from ewes' milk. Finally, like the dry matter content, the ash content of all cheeses was significantly correlated with the age of the cheeses (multiplicative model $r=0.96$ in cheese A, $r=0.89$ in cheese $\mathrm{B}, r=0.91$ in cheese $\mathrm{C}$ and $r=0.91$ in cheese $\mathrm{D}$ ).

Cheeses A and B had significantly $(P<0.05)$ lower salt in moisture $(\mathrm{S} / \mathrm{M})$ content than cheese $\mathrm{D}$ at $13 \mathrm{~d}$ of ripening (table II). Since no other significant difference was observed in the S/M contents of all cheeses throughout ripening, this difference is rather due to the fact that the salt absorption in the cheese mass was not still equilibrated at that time. Compared with other Swiss-type cheeses, Graviera Kritis cheese has higher $\mathrm{S} / \mathrm{M}$ content than Gruyère de Comté and Emmental which have about $2.0 \%$ and $1.2 \% \mathrm{~S} / \mathrm{M}$, respectively $[4,16]$. The S/M content of all cheeses was highly correlated with their age (multiplicative model, $r=0.93$ in cheese A, $r=0.93$ in cheese $\mathrm{B}, r=0.92$ in cheese $\mathrm{C}$ and $r=0.88$ in cheese D) and with the respective values of their dry matter contents $(r=0.75)$. This was expected as generally the increase of salt content of a cheese causes moisture removal from it, limits the extent of proteolysis and consequently affects the $\mathrm{pH}$ increase in the matured cheese $[13,14,22$, 24].

Finally, the starter cultures did not affect, as expected, the fat in dry matter (FDM) content of the matured Graviera Kritis 
Table II. Fat in dry matter and salt in moisture contents ${ }^{1}$ during ripening of Graviera Kritis cheese made with different starter cultures.

Tableau II. Teneurs en matière grasse dans l'extrait sec et en sel dans l'humidité pendant l'affinage du fromage Graviera Kritis fabriqué avec différents levains.

\begin{tabular}{|c|c|c|c|c|c|c|c|c|}
\hline \multirow{2}{*}{$\begin{array}{l}\text { Time } \\
\text { (d) }\end{array}$} & \multicolumn{4}{|c|}{ Fat in dry matter \% } & \multicolumn{4}{|c|}{ Salt in moisture \% } \\
\hline & $A^{2}$ & $\mathrm{~B}^{3}$ & $\mathrm{C}^{4}$ & $\mathrm{D}^{5}$ & A & B & $\mathrm{C}$ & D \\
\hline 1 & 60.90 & 60.10 & 58.27 & 56.36 & 1.14 & 1.30 & 1.11 & 1.31 \\
\hline 13 & 61.97 & 61.28 & 62.32 & 61.72 & $2.38^{\mathrm{a}^{*}}$ & $2.54^{\mathrm{a}}$ & $3.30^{\mathrm{a}, \mathrm{b}}$ & $4.43^{b}$ \\
\hline 30 & $60.19^{\mathrm{a}}$ & $61.46^{a, b}$ & $62.12^{\mathrm{b}}$ & $60.20^{\mathrm{a}}$ & 4.99 & 5.36 & 5.68 & 6.06 \\
\hline 60 & 57.20 & 58.50 & 59.20 & 59.96 & 5.57 & 4.62 & 5.33 & 5.02 \\
\hline 90 & 61.14 & 61.10 & 63.56 & 63.75 & 5.34 & 5.17 & 4.94 & 5.00 \\
\hline 180 & 56.17 & 55.87 & 59.42 & 58.00 & 5.18 & 5.23 & 5.48 & 5.78 \\
\hline
\end{tabular}

${ }^{1}$ Mean values from three trials. ${ }^{2} S$. thermophilus $+L$. helveticus $(1: 1)+$ Propionibacterium freudenreichii subsp. shermanii. ${ }^{3}$ L. lactis subsp. lactis + L. lactis subsp. cremoris $+S$. thermophilus + L. helveticus $(1: 1: 10: 2)+$ Propionibacterium freudenreichii subsp. shermanii. ${ }^{4}$ L. lactis subsp. lactis + L. lactis subsp. cremoris $+S$. thermophilus + L. helveticus $(2.5: 2.5: 1: 1)+$ Propionibacterium freudenreichii subsp. shermanii. ${ }^{5}$ Without starters. $*$ Means in the same row with different superscript differ significantly $(P<0.05)$.

${ }^{1}$ Valeurs moyennes de trois essais. ${ }^{2} S$. thermophilus $+L$ helveticus $(1: 1)+$ Propionibacterium freudenreichii subsp. shermanii. ${ }^{3}$ L. lactis subsp. lactis + L. lactis subsp. cremoris $+S$. thermophilus + L. helveticus $(1: 1: 10: 2)+$ Propionibacterium freudenreichii subsp. shermanii. ${ }^{4} L$. lactis subsp. lactis $+L$. lactis subsp. cremoris $+S$, thermophilus + L. helveticus $(2.5: 2.5: 1: 1)+$ Propionibacterium freudenreichii subsp. shermanii. Sans levains. * Les valeurs moyennes d'une même ligne suivies de lettres différentes different significativement.

cheese (table II). However, the FDM values of all cheeses were high and varied with the cheeses because the fat content of the cheese milk used was not standardized.

\subsection{Microbiological characteristics}

No anaerobic spore-forming microorganism was found in any cheese and this is rather due to the fact that silage food is not used for sheep and goats breeding on Crete island.

On the other hand, as mentioned in the materials and methods section, the raw milk was heavily contaminated, thus the heated cheese milk contained high numbers of NSLAB and contaminants, i.e., coliforms. In addition, a great part of the NSLAB seemed to survive the scalding at $50^{\circ} \mathrm{C}$ as seen in the mesophilic microflora counts of cheese D made without starters (table III). Thus, there was no significant $(P<0.05)$ difference in the mesophilic aerobic microflora counts of cheeses A, B and C made with the starters and cheese $D$ at $1 \mathrm{~d}$ of ripening. This result seems to be in contrast with the $\mathrm{pH}$ difference at the same time (table I), but this happened because the thermophilic starters, which are mainly responsible for the $\mathrm{pH}$ decrease in this cheese at the beginning of ripening, did not grow as rapidly under the conditions used for the enumeration of the mesophilic aerobic microflora. Also, this group possibly contains the survived mesophilic starters of cheeses A, B and C and an heterofermentative mesophilic microflora of cheese D. Finally, from the $13 \mathrm{~d}$ of ripening and after, the 'wild' mesophilic microflora count was significantly higher in cheese $\mathrm{D}$ than in the other cheeses.

With regard to presumptive thermophilic streptococci counts, cheeses A, B and C were also significantly differentiated from cheese D at $13 \mathrm{~d}$ of ripening (table III). This is probably due to the fact that the 'wild' 
Table III. $\log _{10} \mathrm{cfu} \cdot \mathrm{g}^{-1}$ of aerobic mesophilic microflora, thermophilic streptrococci and mesophilic lactobacilli counts ${ }^{1}$ during ripening of Graviera Kritis cheese made with different starter cultures.

Tableau III. Dénombrements (en $\log _{10} \mathrm{ufc}^{-1} \mathrm{~g}^{-1}$ de la flore aérobie mésophile, streptocoques thermophiles et lactobacilles mésophiles pendant l'affinage du fromage Graviera Kritis fabriqué avec différents levains.

\begin{tabular}{|c|c|c|c|c|c|c|c|c|c|c|c|c|}
\hline \multirow[t]{2}{*}{ Time (d) } & \multicolumn{4}{|c|}{ Aerobic mesophilic microflora } & \multicolumn{4}{|c|}{ Presumptive thermophilic streptococci } & \multicolumn{4}{|c|}{ Presumptive mesophilic lactobacilli } \\
\hline & $\mathrm{A}^{2}$ & $\mathrm{~B}^{3}$ & $\mathrm{C}^{4}$ & $\mathrm{D}^{5}$ & A & B & $\mathrm{C}$ & $\mathrm{D}$ & A & B & $\mathrm{C}$ & $\mathrm{D}$ \\
\hline 1 & 8.30 & 8.64 & 8.35 & 8.61 & 8.12 & 8.67 & 8.14 & 8.60 & $7.13^{\mathrm{a}}$ & $8.06^{\mathrm{b}}$ & $7.62^{a, b}$ & $8.40^{\mathrm{b}}$ \\
\hline 13 & $8.00^{\mathrm{a}^{*}}$ & $8.17^{\mathrm{a}}$ & $7.88^{\mathrm{a}}$ & $8.68^{\mathrm{b}}$ & $8.06^{\mathrm{a}}$ & $8.04^{\mathrm{a}}$ & $7.92^{\mathrm{a}}$ & $8.71^{\mathrm{b}}$ & $7.77^{\mathrm{a}}$ & $8.19^{\mathrm{a}}$ & $7.86^{\mathrm{a}}$ & $8.71^{\mathrm{b}}$ \\
\hline 30 & $8.02^{\mathrm{a}}$ & $8.17^{\mathrm{a}}$ & $7.97^{\mathrm{a}}$ & $8.47^{\mathrm{b}}$ & $8.24^{\mathrm{b}, \mathrm{c}}$ & $8.21^{\mathrm{a}, \mathrm{b}}$ & $7.97^{\mathrm{a}}$ & $8.45^{\mathrm{c}}$ & $8.14^{\mathrm{a}}$ & $8.14^{\mathrm{a}}$ & $7.96^{\mathrm{a}}$ & $8.53^{b}$ \\
\hline 60 & $7.79^{a}$ & $8.22^{\mathrm{a}, \mathrm{b}}$ & $7.98^{\mathrm{a}, \mathrm{b}}$ & $8.46^{b}$ & 8.04 & 8.23 & 7.96 & 8.31 & $7.85^{\mathrm{a}}$ & $8.25^{\mathrm{a}, \mathrm{b}}$ & $8.05^{\mathrm{a}, \mathrm{b}}$ & $8.47^{b}$ \\
\hline 90 & $7.91^{\mathrm{a}, \mathrm{b}}$ & $7.97^{\mathrm{a}, \mathrm{b}}$ & $7.72^{\mathrm{a}}$ & $8.30^{\mathrm{b}}$ & $8.13^{\mathrm{a}, \mathrm{b}}$ & $8.01^{\mathrm{a}, \mathrm{b}}$ & $7.96^{\mathrm{a}}$ & $8.35^{b}$ & 8.00 & 8.01 & 7.97 & 8.30 \\
\hline 180 & 7.67 & 8.06 & 7.77 & 7.96 & 8.00 & 8.25 & 7.67 & 8.03 & 7.94 & 8.07 & 7.71 & 8.06 \\
\hline
\end{tabular}

${ }^{1}$ Mean values from three trials. ${ }^{2}$ S. thermophilus + L. helveticus $(1: 1)+$ Propionibacterium freudenreichii subsp. shermanii. ${ }^{3} L$. lactis subsp. lactis + L. lactis subsp. cremoris $+S$. thermophilus $+L$. helveticus $(1: 1: 10: 2)+$ Propionibacterium freudenreichii subsp. shermanii. ${ }^{4}$ L. lactis subsp. lactis + L. lactis subsp. cremoris $+S$. thermophilus + L. helveticus (2.5:2.5:1:1) + Propionibacterium freudenreichii subsp. shermanii. ${ }^{5}$ Without starters. * Means in the same row, followed by different superscript differ significantly $(P<0.05)$.

${ }^{1}$ Valeurs moyennes de trois essais. ${ }^{2} S$. thermophilus + L. helveticus $(1: 1)+$ Propionibacterium freudenreichii subsp. shermanii. ${ }^{3} L$. lactis subsp. lactis + L. lactis subsp. cremoris $+S$. thermophilus + L. helveticus $(1: 1: 10: 2)+$ Propionibacterium freudenreichii subsp. shermanii. ${ }^{4}$ L. lactis subsp. lactis + L. lactis subsp. cremoris + S. thermophilus + L. helveticus $(2.5: 2.5: 1: 1)+$ Propionibacterium freudenreichii subsp. shermanii. ${ }^{5}$ Sans levains. * Les valeurs moyennes d'une même ligne suivies de lettres différentes different significativement. 
streptococci of cheese D grew slowly up to $13 \mathrm{~d}$ of ripening, while the streptococci starters of cheeses A, B and C grew quickly in $1 \mathrm{~d}$ of ripening. According to Mocquot [26], in Swiss-type cheeses the thermophilic streptococci usually reach their highest numbers after $3 \mathrm{~h}$ of the cheese curd pressing. Zerfiridis et al. [29] found that in Greek Gruyère cheese made with cows' milk and ripened at $12{ }^{\circ} \mathrm{C}$ streptococci reached their maximum numbers at $15 \mathrm{~d}$ of ripening.

Mesophilic lactobacilli, which constitute the main part of the NSLAB $[11,25]$, grew more rapidly in cheese $D$ than in cheeses $\mathrm{A}, \mathrm{B}$ and $\mathrm{C}$ (table III). The mesophilic lactobacilli in cheese $\mathrm{D}$ reached their maximum count at $13 \mathrm{~d}$ of ripening, while in cheeses A, B and C at 30 and/or $60 \mathrm{~d}$ of ripening. Therefore, significant $(P<0.05)$ differences in the mesophilic lactobacilli counts among cheese $\mathrm{D}$ and the others were observed up to $60 \mathrm{~d}$ of ripening.

Taking into consideration the above results, it seems that, the growth of the starters in cheeses A, B and C was partially suppressed by the 'wild' microflora, i.e., NSLAB and coliforms. According to Langsrud and Reinbold [19], even if the milk is sufficiently pasteurized, the initial microbiological quality of the raw milk and the types of microorganisms present in it severely affect the ripening processing and finally the Swiss cheese quality. The high numbers of coliforms in the cheese milk generally inhibit the lactic acid bacteria growth during the manufacture of Gruyère cheese, while Enterobacter aerogenes and $E$. coli specifically inhibit the lactobacilli and streptococci growth, respectively. On the other hand, coliforms are sensitive to acid conditions caused in a cheese by lactic acid starter cultures [7]. Therefore, the low $\mathrm{pH}$ of cheeses $\mathrm{A}, \mathrm{B}$ and $\mathrm{C}$ at $\mathrm{I}$ d of ripening (table I) inhibited the coliforms growth and thus, their counts decreased gradually up to $30 \mathrm{~d}$ of ripening (table IV). On the contrary, the coliforms counts in cheese D were significantly higher and they were detected up to $90 \mathrm{~d}$ of ripening. Zerfiridis et al. [29] have also reported that the coliforms counts in a Greek Gruyère cheese made with starters decreased dramatically after $4 \mathrm{~d}$ of ripening.

Enterococci, which are expected to be a great part of the NSLAB in these cheese types, were present in all cheeses throughout ripening. However, their counts in cheese D were significantly $(P<0.05)$ higher than in cheeses $\mathrm{A}, \mathrm{B}$ and $\mathrm{C}$ (table IV). It is also noteworthy that in cheeses $\mathrm{A}, \mathrm{B}$ and $\mathrm{C}$ enterococci counts decreased after $60 \mathrm{~d}$ of ripening, while in traditional cheese D they remained constant throughout ripening. On the contrary, in the Greek Gruyère cheese studied by Zerfiridis et al. [29] enterococci almost disappeared at the end of ripening.

As far as the propionibacteria are concerned, cheese $\mathrm{D}$ had significantly $(P<0.05)$ lower counts than cheeses $B$ and $C$ throughout ripening (table IV). The propionibacteria of cheese $D$ were from the native microflora of the raw milk, because many of them survived the heat treatment. According to Gautier et al. [15], propionibacteria can survive the HTST pasteurization, $72^{\circ} \mathrm{C}$ for 15 s (HTST: high temperature short time). In a Swiss-type cheese, however, the propionibacteria growth is dependent on several combined factors. Propionibacteria are very sensitive to salt and they need a salt in moisture content less than $2 \%$ in order to grow [5, $20,23]$. Moreover, their growth rate and the $\mathrm{CO}_{2}$ production are greatly affected by the $\mathrm{pH}$ of cheese which should be comprised between 5.2 and 5.4 at the first $d$ of ripening $[20,23]$. The propionibacteria growth is also dependent on the ripening temperature. They can grow at numbers up to $10^{8}-10^{9} \mathrm{cfu} \cdot \mathrm{g}^{-1}$ within two months in a 'warm' room with a temperature of 20-22 ${ }^{\circ} \mathrm{C}$ for Emmental cheese and $16-18{ }^{\circ} \mathrm{C}$ for Comté cheese [7]. Therefore, propionibacteria in cheeses A, B and C, all made with propionic starter culture, did not grow at levels as high as expected because of, firstly, the high salt in moisture contents and, secondly, the low $\mathrm{pH}$ at the first d (table I) 
Table IV. $\log _{10} \cdot \mathrm{cfu} \cdot \mathrm{g}^{-1}$ of coliforms, enterococci and propionibacteria counts ${ }^{1}$ during ripening of Graviera Kritis cheese made with different starter cultures.

Tableau IV. Dénombrements (en $\log _{10} \cdot \mathrm{cfu} \cdot \mathrm{g}^{-1}$ ) des coliformes, entérocoques et bactéries propioniques pendant l'affinage du fromage Graviera Kritis fabriqué avec différents levains.

\begin{tabular}{|c|c|c|c|c|c|c|c|c|c|c|c|c|}
\hline \multirow[t]{2}{*}{ Time (d) } & \multicolumn{4}{|c|}{ Coliforms } & \multicolumn{4}{|c|}{ Enterococci } & \multicolumn{4}{|c|}{ Propionibacteria } \\
\hline & $\mathrm{A}^{2}$ & $\mathrm{~B}^{3}$ & $\mathrm{C}^{4}$ & $\mathrm{D}^{5}$ & A & B & $\mathrm{C}$ & $\mathrm{D}$ & A & B & $\mathrm{C}$ & D \\
\hline 1 & $2.16^{\mathrm{a}^{*}}$ & $1.93^{\mathrm{a}}$ & $2.62^{\mathrm{a}}$ & $4.74^{b}$ & $3.95^{\mathrm{a}}$ & $5.19^{b}$ & $5.02^{\mathrm{b}}$ & $6.38^{c}$ & $3.41^{\mathrm{a}}$ & $4.63^{\mathrm{a}, \mathrm{b}}$ & $5.23^{b}$ & $3.63^{\mathrm{a}}$ \\
\hline 13 & $0.93^{\mathrm{a}}$ & $0.63^{\mathrm{a}}$ & $0.74^{\mathrm{a}}$ & $5.01^{\mathrm{b}}$ & $4.02^{\mathrm{a}}$ & $4.18^{\mathrm{a}}$ & $4.42^{\mathrm{b}}$ & $6.68^{c}$ & $3.75^{\mathrm{a}}$ & $5.55^{\mathrm{b}}$ & $5.33^{\mathrm{b}}$ & $3.95^{\mathrm{a}}$ \\
\hline 30 & 0 & 0 & $0.59^{\mathrm{a}}$ & $3.69^{b}$ & $6.18^{\mathrm{a}, \mathrm{b}}$ & $4.75^{\mathrm{a}}$ & $5.27^{\mathrm{a}, \mathrm{b}}$ & $6.88^{b}$ & $4.73^{\mathrm{a}, \mathrm{b}}$ & $6.05^{\mathrm{c}}$ & $5.78^{b, c}$ & $4.53^{\mathrm{a}}$ \\
\hline 60 & & & 0 & 2.10 & $6.49^{\mathrm{a}, \mathrm{b}}$ & $5.98^{\mathrm{a}, \mathrm{b}}$ & $5.29^{a}$ & $6.84^{b}$ & 4.45 & 6.34 & 6.30 & 4.90 \\
\hline 90 & & & & 0.92 & 4.98 & 5.36 & 5.67 & 6.92 & $5.35^{\mathrm{a}, \mathrm{b}}$ & $6.10^{\mathrm{a}, \mathrm{b}}$ & $6.71^{\mathrm{b}}$ & $5.02^{\mathrm{a}}$ \\
\hline 180 & & & & 0 & $3.64^{\mathrm{a}}$ & $3.87^{\mathrm{a}}$ & $4.11^{\mathrm{a}}$ & $6.84^{b}$ & 4.03 & 4.42 & 4.44 & 3.84 \\
\hline
\end{tabular}

${ }^{1}$ Mean values from three trials. ${ }^{2}$ S. thermophilus + L. helveticus $(1: 1)+$ Propionibacterium freudenreichii subsp. shermanii. ${ }^{3} L$. lactis subsp. lactis + L. lactis subsp. cremoris $+S$. thermophilus + L. helveticus $(1: 1: 10: 2)+$ Propionibacterium freudenreichii subsp. shermanii. ${ }^{4}$ L. lactis subsp. lactis + L. lactis subsp. cremoris + S. thermophilus $+L$. helveticus $(2.5: 2.5: 1: 1)+$ Propionibacterium freudenreichii subsp. shermanii. ${ }^{5}$ Without starters. $*$ Means in the same row, followed by different superscript differ significantly $(P<0.05)$.

${ }^{1}$ Valeurs moyennes de trois essais. ${ }^{2}$ S. thermophilus + L. helveticus $(1: 1)+$ Propionibacterium freudenreichii subsp. shermanii. ${ }^{3}$ L. lactis subsp. lactis + L. lactis subsp. cremoris $+S$. thermophilus $+L$. helveticus $(1: 1: 10: 2)+$ Propionibacterium freudenreichii subsp. shermanii. ${ }^{4} L$. lactis subsp. lactis $+L$. lactis subsp. cremoris $+S$. thermophilus + L. helveticus $(2.5: 2.5: 1: 1)+$ Propionibacterium freudenreichii subsp. shermanii. ${ }^{5}$ Sans levains. * Les valeurs moyennes d'une même ligne suivies de lettres différentes diffèrent significativement. 
Table V. Flavour, body and texture ${ }^{1}$ at 90 and $180 \mathrm{~d}$ of ripening of Graviera Kritis cheese made with different starter cultures.

Tableau V. Flaveur et texture ${ }^{1}$ à 90 et $180 \mathrm{j}$ d'affinage du fromage Graviera Kritis fabriqué avec différents levains.

\begin{tabular}{|c|c|c|c|c|c|c|c|c|}
\hline \multirow{2}{*}{$\begin{array}{l}\text { Time } \\
\text { (d) }\end{array}$} & \multicolumn{4}{|c|}{ Flavour $(0-45)$} & \multicolumn{4}{|c|}{ Body and texture $(0-35)$} \\
\hline & $\mathrm{A}^{2}$ & $\mathrm{~B}^{3}$ & $\mathrm{C}^{4}$ & $\mathrm{D}^{5}$ & A & B & $\mathrm{C}$ & D \\
\hline 90 & 37.90 & 36.30 & 35.70 & 34.80 & 28.20 & 25.40 & 26.50 & 26.90 \\
\hline 180 & 36.33 & 35.66 & 32.33 & 34.75 & 27.83 & 26.58 & 25.00 & 26.83 \\
\hline
\end{tabular}

${ }^{1}$ Mean values from three trials, ${ }^{2} S$. thermophilus $+L$. helveticus $(1: 1)+$ Propionibacterium freudenreichii subsp. shermanii. ${ }^{3}$ L. lactis subsp. lactis + L. lactis subsp. cremoris $+S$. thermophilus + L. helveticus $(1: 1: 10: 2)+$ Propionibacterium freudenreichii subsp. shermanii. ${ }^{4}$ L. lactis subsp. lactis + L. lactis subsp. cremoris + S. thermophilus + L. helveticus $(2.5: 2.5: 1: 1)+$ Propionibacterium freudenreichii subsp. shermanii. ${ }^{5}$ Without starters.

${ }^{1}$ Valeurs moyennes de trois essais. ${ }^{2} S$. thermophilus $+L$. helveticus $(1: 1)+$ Propionibacterium freudenreichii subsp. shermanii. ${ }^{3}$ L. lactis subsp. lactis + L. lactis subsp. cremoris $+S$. thermophilus + L. helveticus $(1: 1: 10: 2)+$ Propionibacterium freudenreichii subsp. shermanii. ${ }^{4}$ L. lactis subsp. lactis $+L$. lactis subsp. cremoris $+S$. thermophilus + L. helveticus (2.5:2.5:1:1) + Propionibacterium freudenreichii subsp. shermanii. ${ }^{5}$ Sans levains.

and the low ripening temperature of these cheeses. In Greek Gruyère cheese, made with propionic starter culture, propionibacteria were also found to be up to $10^{5} \mathrm{cfu} \cdot \mathrm{g}^{-1}$ at $45 \mathrm{~d}$ of ripening [29].

\subsection{Organoleptic characteristics}

The different starter cultures used in this experiment did not seem to affect significantly the flavour and the body and texture characteristics of Graviera Kritis cheese. All cheeses had the typical flavour of Graviera Kritis cheese at 90 and 180 d of ripening and thus scored similarly (table $\mathrm{V}$ ). No sweet taste was observed in any case and this fact coincides with the limited growth of propionibacteria in all cheeses (table IV). The texture of all cheeses was not elastic and apart from a few slits there were no eyes. The texture characteristics could possibly be attributed to the high salt in moisture and dry matter contents and also to the low $\mathrm{pH}$ values of the cheeses at the end of ripening, since these parameters seem to affect the eye formation in a Gruyère-type cheese. According to Berdagué and Grappin [3], the eye formation in gruyère de Comté is nega- tively correlated with the salt $(r=-0.36)$ and dry matter $(r=-0.33)$ contents, while the split defect intensity is positively correlated with the $\mathrm{pH}(r=0.50)$ at the end of ripening.

\section{CONCLUSIONS}

This work showed that the starters used in the manufacture of Graviera Kritis cheese influenced only the raw milk flora growth and in particular the coliforms and enterococci growth. Consequently, the use of a certain inoculum level of selected starter cultures in the manufacture of Graviera Kritis cheese could be useful in order to control and improve the cheese quality without significantly changing the typical organoleptic characteristics of this cheese.

\section{ACKNOWLEDGMENTS}

The authors wish to thank the Agricultural Cooperative Organization of Rethimnos for its help in the cheesemaking and the Greek Ministry of Industry, Energy and Technology for financial support. 


\section{REFERENCES}

[1 Anifantakis E., Veinoglou B., Kandarakis I., Manufacture of Gruyere-type cheese with 50:50 rennet/swine pepsin, J. Dairy Res. 48 (1981) 513-518.

[2] Anifantakis E., Methods for Analysing Milk and Milk Products, Karaberopoulos editions, Athens, Greece, 1982.

[3] Berdagué J.L., Grappin R., Affinage et qualité du gruyère de Comté VII. Caractéristiques de présentation : ouverture et défaut de lainure des fromages, Lait 69 (1989) 173-181.

[4] Berdagué J.L., Grappin R., Delacroix-Buchet A., Chaillet B., Caractérisation de l'emmental « grand-cru » francais. I. Composition physicochimique, Lait 70 (1990) 1-14.

[5] Carcano M., Todesco R., Lodi R., Brasca M., Propionibacteria in Italian hard cheeses, Lait 75 (1995) 415-426.

[6] Choisy C., Desmazeaud M., Gripon J.C., Lamberet G., Lenoir J., Tourneur C. Microbial and biochemical aspects of ripening, in: Eck A. (Ed.), Cheesemaking, Science and Technology, Lavoisier publishing Inc, New York, 1987, pp. 89-100.

[7] Choisy C., Guéguen M., Lenoir J., Schmidt J.L., Tourneur $\mathrm{C}_{\text {., }}$ The ripening of cheese, Microbiological aspects, in; Eck A. (Ed.), Cheesemaking, Science and Technology, Lavoisier Publishing Inc, New York, 1987, pp. 259-292.

[8] Commission Regulation (EC) No 1107/96 on the registration of geographical indications and designations of origin under the procedure laid down in Article 17 of Council Regulation (EEC) No 2081/92, Official Journal of the European Communities No L 148 /1-10.

[9] Creamer L.K., Water absorption by renneted casein micelles, Milchwissenschaft 40 (1985) 589-591.

[10] Crow V.L. Utilization of lactate isomers by Propionibacterium freudeureichii subsp. shermanii: regulatory role for intracellular pyruvate, Appl. Environ. Microbiol 52 (1986) 352-358.

[11] Demarigny Y., Beuvier E., Dasen A., Duboz G., Influence of raw milk microflora on the characteristics of Swiss-type cheeses, I. Evolution of microflora during ripening and characterization of facultatively heterofermentative lactobacilli, Lait 76 (1996) 371-387.

[12] Drinan F.D., Cogan T.M., Detection of propionic acid bacteria in cheese, J. Dairy Res. 59 (1992) 65-69.

[13] Fox P.F., Significance of salt in cheese ripening, Dairy Ind. Int. 52 (1987) 19-22.

[14] Fox P.F., Proteolysis during cheese manufacture and ripening, J. Dairy Sci. 72 (1989) 1379-1400.

[15] Gautier M., Lortal S., Boyaval P., Girard F., Lemée R, de Carvalho A.F., Dupuis C., Les bactéries propioniques laitières, Lait 73 (1993) 257-263.

[16] Grappin R., Berdagué J.L., Affinage et qualité du gruyère de Comté VIII. Synthèse et conclusions, Lait 69 (1989) 183-196.

[17] IDF Standard 73A, Enumeration of coliforms, (1985)

[18] Kalantzopoulos G.C., Cheeses from ewes' and goats' milk, in: Fox P.F. (Ed.) Cheese, Chemistry, Physics and Microbiology, 2. Major Cheese Groups, Chapman \& Hall, London, 1993, pp. 507-553.

[19] Langsrud T., Reinbold G.W., Flavor development and microbiology of Swiss cheese - A review I. Milk quality and treatments, J. Milk Food Tech. 36 (1973) 487-490.

[20] Langsrud T., Reinbold G.W., Flavor development and microbiology of Swiss cheese - A review II. Starters, manufacturing processes and procedures, J. Milk Food Tech. 36 (1973) 531-542.

[21] Langsrud T., Reinbold G.W., Flavor development and microbiology of Swiss cheese - A review III. Ripening and flavour production, J. Milk Food Tech. 36 (1973) 593-609.

[22] Law B.A., Proteolysis in relation to normal and accelerated cheese ripening, in: Fox P.F. (Ed.), Cheese, Chemistry, Physics and Microbiology. 1. General Aspects, Elsevier Applied Science, 1987, pp. 365-392

[23] Lawrence R.C., Heap H.A., Gilles J., A Controlled Approach to cheese Technology, J. Dairy Sci. 67 (1984) 1632-1645.

[24] Lawrence R.C., Creamer L.K., Gilles J., Texture development during cheese ripening, J. Dairy Sci. 70 (1987) 1748-1760.

[25] Martley F.G., Crow V.L., Interactions between non-starter microorgnisms during cheese manufacture and ripening, Int, Dairy J. 3 (1993) 461-483.

[26] Mocquot G., Reviews of the progress of Dairy Science: Swiss-type cheese, J. Dairy Res. 46 (1979) 133-160.

[27] Steffen C., Eberhard P., Bosset J.O., Ruegg M., Swiss-type varieties, in: Fox P.F. (Ed.), Cheese, Chemistry, Physics and Microbiology. 2. Major Cheese Groups, Chapman and Hall, London, 1993, pp. 83-110.

[28] Veinoglou B.K., Erland S., Kalantzopoulos G.. Stamelos N.K., Composition of Gruyere-type cheese made from ewes' milk. Yield of cheese and other products, Delt. Agrot. Trapezas No 159 [DSA 1969: 2034], 1968.

[29] Zerfiridis G., Vafopoulou-Mastrogiannaki A., Litopoulou-Tzanetaki E., Changes during ripening of commercial Gruyere cheese, J. Dairy Sci, 67 (1984) 1397-1405. 